\title{
\#12
}

\section{Idealisme Jurnalis dan Pertimbangan Moral Pemberitaan}

\author{
Noviawan Rasyid Ohorella \& Priska Akwila Birahy
}

Indonesia tidak bisa lepas dari perkembangan media, baik itu cetak maupun elektronik. Pemerintahan maupun masyarakat menjadikan media sebagai wadah komunikasi informasi. Dalam konteks ini Media terus berevolusi bukan sekedar memberitakan pencapaian pemerintah, tetapi mengakomodir kemauan dan apa saja yang dibutuhkan oleh masyarakat. Terlepas dari hal ini pers yang sebelumnya mengkonsepkan diri sebagai sebagai media pembangunan yang mengedepankan kekuasaan, berubah menjadi transparansi dan demokratisasi komunikasi informasi (Eko Harry, 2009).

Era 4.0 yang sedang di alami Indonesia, mengharuskan masyarakat untuk mendapatkan informasi. Hal ini menjadikan media massa untuk dapat mengonstruksi pesan informasi agar mampu dinikmati dan menjadi edukasi bagi masyarakat. Media dituntut untuk mampu mengemas informasi dengan baik dan mengikuti etika 
jurnalistik, namun ada kalanya jurnalis dan media memiliki idealisme yang berbeda dan akhirnya berpengaruh terhadap kualitas informasi serta sudut pandang yang diberitakan.

Jurnalis pada dasarnya memiliki tugas dan tanggung jawab untuk memberitakan berbagai peristiwa yang mampu mengedukasi masyarakat. Pemilihan berita, penulisan, gaya penyampaian hingga dipublikasikan kepada masyarakat harus sesuai dengan kode etik jurnalistik. Namun saat ini idealisme merubah segalanya, ada perpsektif yang timbul untuk mempengaruhi pemberitaan dan nilai pesan informasi.

Berbicara mengenai kode etik jurnalistik, karena hal ini berkaitan erat dengan idealism jurnalis maupun idealism media itu sendiri. Surat Keputusan Dewan Pers Nomor 03/SK-DP/III/2006, menyangkut ketentuan yang harus di ikuti oleh Jurnalis diantaranya:

1. Bersikap independen, hal ini menjadi dasar bagi para jurnalis diberbagai media untuk dapat mengesampingkan ego dan tetap memberitakan berbagai peristiwa dengan nilai kualitas informasi yang mumpuni.

2. Menempuh cara professional dalam melaksanakan tugas, dalam hal ini apa yang disampaikan kepada publik adalah benar - benar peristiwa yang tidak dikosntruksi untuk memperkuat idealism.

3. Menguji informasi, adanya keseimbangan dan tidak mencampur adukkan antara fakta lapangan dan opini pribadi sehingga dapat menimbulkan bias informasi, untuk meminimalisir hal ini dengan sikap praduga tidak bersalah.

4. Menghormati hak pribadi narasumber, berupaya semaksimal mungkin untuk menginformasikan apa yang semestinya di informasikan tanpa harus menjatuhkan dan menghakimi narasumber.

5. Wartawan Indonesia segera mencabut, meralat, dan memperbaiki berita yang keliru dan tidak akurat dengan 
disertai permintaan maaf kepada pembaca, pendengar atau pemirsa.

6. Wartawan melayani hak jawab dan koreksi secara professional.

Dari ketentuan yang harus di ikuti oleh Jurnalis, ada tuntutan untuk menjalankan apa yang dinamakan dengan transparansi informasi yang tertuang dalam Undang - Undang No. 14 Tahun 2008, tentang Keterbukaan Informasi Publik. Hal ini terfokus pada bagaimana Jurnalis dan Media mampu untuk memberitakan peristiwa atau kejadian secara berkala dan informasi yang wajib disampaikan kepada masyarakat sebagai bagian dari ketersediaan pesan informasi.

Pers tumbuh dengan baik di Indonesia, ditandai dengan banyaknya media yang bermunculan baik itu cetak, elektronik, dan sosial media. Nilai positif yang diambil adalah banyaknya informasi yang dapat diketahui oleh masyarakat dengan berbagai sudut pandang yang disajikan oleh jurnalis dan media bersangkutan. Namun yang patut diawasi adalah penyebaran berita hoax, disinformasi, dan permainan idealism dalam mengonstruksi pemberitaan kepada masyarakat.

Esensi perubahan dalam perkembangn pers, ditandai dengan banyaknya media yang lahir dan konsep yang awalnya dikendalikan pemerintah atau penguasa, sudah berubah menjadi pers bebas yang tetap mematuhi kode etik jurnalistik. Pengawasan dan kontrol penuh selain dari dewan pengawas, namun juga masyarakat agar selalu mengawal berbagai pesan informasi yang diterima agar tidak timbul disinformasi yang dapat menimbulkan pro kontra (Taufik Akhyar, 2015).

Idealisme jurnalis merupakan jati diri yang dimiliki dalam memberitakan dan mengemas berbagai peristiwa yang ada, namun idelisme jangan sampai menurunkan kualitas pesan informasi yang 
akan disampaikan. Idealism di identikkan dengan pelaksanaan fungsi perss yaitu menyebarluaskan informasi, mendidik, menghibur, mempengaruhi, dan menjalankan fungsi secara seimbang. (Onong Uchjana, 2000) mengatakan bahwa pengelolaan pers terdiri dari dua dimensi yaitu dimensi ideal dan dimensi komersial. Dalam hal ini idealism digunakan untuk kegiatan jurnalistik dan dilain sisi idealism berguna dalam perkembangan lembaga pers bersangkutan.

Jurnalis dituntut untuk dapat berkarya dengan tanggung jawab utamanya yaitu memberitakan dan menyampaikan informasi secara independensi, kebenaran data, dan dampak sosial informasi. Namun jika berbicara terkait dengan industri media aka nada yang dinamakan orientasi media yang berfokus pada kebutuhan masyarakat serta profit kapitalis. (McQuail, 2002) dalam bukunya Mass Communication Theories, bahwa ada 6 perspektif dalam melihat peran media diantaranya :

1. Window of events and experience, melihat sesuatu yang terjadi diluar maupun diri sendiri.

2. A mirror of events in society and the world, implying a faithful reflection, refleksi peristiwa yang ada di masyarakat dan dunia.

3. Filter or gatekeeper, menyeleksi berbagai hal yang terjadi.

4. Guide, menunjukkan arah dari ketidakpastian pesan informasi.

5. Forum representative, berbagai ide dan tanggapan yang ada.

6. Interlocutor, sebagai partner komunikasi yang interaktif.

Ketersediaan informasi publik menjadikan media sebagai ruang publik bukan hanya sekedar mendapatkan informasi, tetapi berupaya mengawal dan berinteraksi dengan siapapun terkait pesan informasi yang di dapat. Media sebagai ruang publik, memungkinkan masyarakat membicarakan peristiwa yang terjadi tanpa adanya intervensi dari penguasa maupun lainnya (Jamhur Poti, 2019). 
Penjabaran diatas juga berlaku pada daerah - daerah di Indonesia yang masyarakatnya bukan hanya mengetahui dari media nasional, tetapi media lokal juga sebagai ruang publik untuk membantu dalam menyampaian pesan informasi yang dibutuhkan. Media lokal saat ini hadir untuk memberikan ruang yang lebih untuk berbagai peristiwa atau kejadian yang tidak diberitakan oleh media nasional. Hal ini tentu memberikan dampak positif dalam pertukaran komunikasi informasi secara berkesinambungan dan bertahap.

Provinsi Maluku dalam hal ini memiliki 11 Kabupaten/Kota yang secara geografi berbeda pulau. Memerlukan wadah dalam pemberitaan berbagai macam peristiwa, sehingga pemenuhan informasi terus ada dan masyarakat dapat berinteraksi dengan pemberitaan yang disampaikan. Sebagai daerah di Indonesia bagian timur, media sudah pasti menjadi barang yang bernilai untuk pemenuhan kebutuhan informasi. Karena media nasional tidak secara langsung mengakomodir pemberitaan lokal yang ada di daerah.

Jurnalis dan media daerah adalah penggerak literasi dan menjadi garda terdepan untuk memberitakan Good News yang jarang orang ketahui. Karena idealisme jurnalis yang ada di daerah juga berkaitan erat dengan identitas budaya serta kehidupan sosial masyarakat. Media berupaya sebaik mungkin agar informasi komunikasi dapat terus ada kepada masyarakat.

Sebagai garis nyata yang bisa kita pahami, yakni peliputan selama covid. Dimana andemic covid bermula dari Wuhan. Virus yang bergerak masuk menjangkit mulai dari wilayah sekitar Wuhan lalu bergerak menuju negara-negara sekitar di satu daratan satu benua hingga ke semua penjuru.

Maka dengan jalur yang sama pula produk berita dan kerja para jurnalis berjalan seirama. Sumber-sumber data berpusat pada lokasi paling utama di satu wilayah. Bagi jurnalis daerah, apa kata 
narasumber di ibukota negara akan sangat menentukan langkah yang diambil di daerah. Sudah semestinya jika itu berpaku pada teks-teks media, maka jurnalis memberitakan apa yang jadi sumber utama dan terkuat. Kebutuhan untuk konfirmasi, menggali data tambahan, narasumber sekunder, mencari padanan kasus serupa tentu perlu. Hanya saja dalam praktik di lapangan, hal itu bisa banyak berubah.

Isu pandemik, penyakit, kasus kematian, jumlah penderita, angka terbanyak, dan zonasi adalah kabar yang paling dinanti. Kementerian, BPOM, WHO, dan Presiden merupakan sumber utama terpercaya. Dari situlah banyak liputan kritis yang dapat diberitakan. Penyampaian informasi dari lembaga-lembaga ini merupakan menu sarapan utama warga negara. Hanya saja dalam praktik di lapangan ada sejumlah penyesuaian.

Dari pengalaman penulis saja, ada pertimbangan etis pribadi dan sosial atas semua data mentah dari pusat. Apakah iya masyarakat kita butuh itu, apakah mereka tahu dan sanggup mendengar jumlah itu. Memang bagi media di arus utama ibu kota, itu menjadi bahan tulisan apik. Paling banyak diklik. Tapi bagi kami di daerah, ada saringan yang mesti kami pastikan ia berada di posisi terbaik.

Sebagai contoh saat mulai ramai kata zonasi muncul. Terjadi pedebatan di antara wartawan usai Juru Bicara Covid-19 Maluku kala itu, Kasrul Selang menerbitkan pernyataan bahwa Maluku masuk zona merah. Sementara di waktu yang sama jurnalis daerah terus memutakhirkan data dari pusat. Belum ada zonasi demikian di Maluku. Bahkan pernyataan 'wow' itu tidak disertai dengan indikator, alasan mapun kriteria zona merah.

Sontak seisi ruangan konferensi pers gaduh. Kami saling tanya, heran, bingung, antara kaget dengan perkembangan covid atau mempertanyakan pernyataan itu. Ini terjadi pada 28 April 2020 Jangankan di Maluku, di Jakarta pun aturan zonasi masih awam. 
Asing di telinga. Meski kami yakin bahwa kami sendiri sangsi namun pernyataan itu adalah bahan berita paling laris. Di lain sisi sudah ada satu kasus kala itu di Maluku. Orang daerah seperti kami di timur Indonesia panik, takut dan bingung harus bagaimana. Pemberitaan media menjadi jendela bagi masyarakat. Sudah tentu di atas meja redaksi 'Maluku Zona Merah' bakal menggemparkan.

Namun di sinilah letak permasalahannya. Saat kita dituntut untuk memberitakan di jalur idealisme, harus ada pertimbangan moral lain yang dijaga. Zona merah memberi efek buruk psikologis penduduk yang tak sampai setengah Kota Jakarta ini. Prediksi praktis kami, akan ada kepanikan, orang memburu apotik membeli masker dan hand sanitizer. Sudah pasti ada banyak yang tidak kebagian. Tidak ada yang berbelanja selama beberapa waktu, krisis makanan, krisis kantong, lalu terbitlah pesan berantai dari satu grup ke grup lain soal si merah. Apakah ini muara idealisme yang harus kami pertahankan.

Kami sendiri berkerja di media online. Namanya Terasmaluku.com. Satu-satunya media online yang terverifikasi dewan pers dari Maluku. Tanggung jawab kami besar. ada kepercayaan, martabat dan marwah jurnalis di meja redaksi dan di ujung kalimat setiap berita.

Perkara zona merah Kami sebagai jurnalis bertanggungjawab memberikan kabar 'buruk' ini kepada pembaca sekaligus tidak lupa alasannya. Hal ini lalu kami ceritakan kembali kepada pemimpin redaksi di kantor. Atas segala pertimbangan kami bersihkerah untuk tidak mempublikasikan berita.

Sementara media online lain sudah lebih dulu memuat. Warganet di media sosial telah menyebar berita ini ke segala lini. Hanya kami yang pending. Dengan usaha keras, kami mencari kontak si juru bicara, kemduain ketemu dan hal ini langsung kami beritakan. Pada isi chat terkonfirmasi pernyataan berbeda. Dari situ jadi landasan 
kami membuat pemberitaan dengan judul "Ambon Zona Merah, Jubir Covid-19 RI : Yang Bilang Merah Siapa".

Di meja redaksi kami dan pemimpin redaksi sempat berdiskusi mengenai ini. Alhasil berita tayang pada malam hari. Sudah lama jam pastinya tapi di atas pukul 21.00 WIT. Sempat ada rasa tak enak lantaran rekan dari media lain lebih dulu mengunggah berita. Namun siapa sangka hingga pagi nyatanya berita dari media kamilah yang paling banyak dibagikan. Kami mendapat puluhan tag dan ratusan komentar dari warga net mengenai sudut pandang dan cara pemberitaan yang beda. Tentu dengan narasumber kelas A1 media kami yang unggul. Padahal jika dilihat platform media online amat mendahulukan kecepatan. Pada ragam literasi, text book media online masuk dalam kategori media baru yang mengedepankan kecepatan dan praktis (Straubhaar \& LaRose, 2006).

Dalam praktiknya belakangan, hal itu tak sepenuhnya berlaku. Kecepatan bagi media online bukan hal utama. Bahkan tubuh berita yang dibuat singkat pun tak lagi menarik. tetap ada pembaca yang memilih membaca berita online dengan tubuh panjang. Jika salah satu ciri khas media online adalah singkat padat dan jelas. Tapi itu semua bisa berubah, Terbantahkan. Adakalanya kondisi sosial masyarakat dapat menggeser sifat media dimana kita bernaung. Mengapa demikian. Jelas karena pembaca kita pun berubah. Pada awal kemunculan media online sebesar Kompas.com pada 1997. Memang benar dan tak ada yang salah. Sebab kebutuhan saat itu demikian. Orang mulai merasa bosan jika harus memegang koran atau majalah yang besar dan tebal. Mereka butuh sesuatu yang praktis. Lama kelamaan, dinamika sosial yang bergerak cepat menuntut media online mampu menyajikan menu berita singkat padat jelas lezat.

Berhenti di situ, tentu tidak. Semakin hari perubahan perilaku pembaca jadi indikator pergeseran sifat media. Orang tak lagi 
mencari yang singkat singkat. Sebab terbukti ada banyak berita yang jangkap hingga hoaks. Hanya karena penulis tidak mampu menyajikan banyak data dan fakta mendukung kalimat-kalimat beritanya.

Hal lain yang tak kalah penting dari perkembangan media baru adalah soal eksistensi entitas lokal. Penulis sebelumnya pernah mengabdi sebagai jurnalis di Jawa Pos koran Surabaya selama 4 tahun dan 1 tahun di Jawa Pos Koran Jakarta. Di dua kota ini penulis menempati rubrik utama dan punggawa. Yakni Metropolis di Surabaya dan Metropolitan di Jakarta. Wajah Jawa Pos berada pada dua kategori tersebut. bekerja di situ membawa penulis mempelajari tipe psikologi, kecenderungan memilih, sifat, budaya, hingga latar ekonomi masyarakat.

Sebagi sontoh, di Surabaya. Penulis mengibaratkan Surabaya sebagai kampung besar. Masyarakatnya sudah maju, banyak mall, toko keren, aktivitas kekinian anak muda. Namun mereka tidak individualis seperti Jakarta. warganya masih guyub, suka nimbrung, suka kepo, suka ngurusin sana sini. Dan itu artinya rasa ingin terlihat dan menonjol sangat tinggi.

Maka tak heran perjalanan informasi di Surabaya amat terbuka. Masyarakatnya sangat legowo, kuat, dan suka melahap banyak berita. Berbeda dengan di Jakarta yang cenderung apatis, masa bodoh dan pilih-pilih.

Peneterasi kerja jurnalis di kota tersebut turut terpengaruh. Nah, gambaran serupa juga yang ada di Ambon. Rentang waktu dan jarak yang jauh dari ibukota membuat adanya disparitas informasi. Tidak mesti semua berita dari pusat kita telan mentah-mentah. Adakalanya butuh waktu mendiamkan adonan agar ragi mengembang. Atau mendiamkan kocokan telur putih agar busanya hilang. 
Apapun platform medianya, indikator-indikator itu yang kini jadi penentu perubahan. kita tidak bisa berbicara idealism secara sertamerta. Sementara masih ada gerbong laba perushaan media yang mesti kita pikirkan. Hanya bagian itu bukan jadi tanggungjawab besar. Biasanya ada di tangan pemimpin redaksi.

\section{Referensi}

Eko Harry Susanto. 2009. Tanggung Jawab Jurnalis dan Idealisme Media. Jurnal Visi Komunikasi. Vol 2 No 2 Juni 2009.

Taufik Akhyar . 2015. Manajemen Pers : Antara Idealisme dan Komersialisme. Jurnal Intizar Raden fatah. Vol 21 No 12015.

https://www.kompasiana.com/image/amazia/5a18c12cc81c633654424082/k emunculan-media-online-di-indonesia.

https://terasmaluku.com/ambon-zona-merah-jubir-covid-19-ri-yang-bilangmerah-siapa/.

\section{Profil Penulis}

Noviawan Rasyid Ohorella, S.I.Kom. atau yang akrab dipanggil "Opi" memperoleh gelar sarjana komunikasi di Universitas Gunadarma, kemudian melanjutkan studi pada Program Pasca Sarjana Magister IImu Komunikasi Universitas Gunadarma. Pengalaman Jurnalis nya dimulai saat bergabung di Media Online Lensatimur pada Tahun 2018 dan saat ini menjadi Jurnalis di Media Online Tifa Magazine dari Tahun 2020.

Priska Akwila Birahy, S.I.Kom. atau yang akrab dipanggil "Ika" merupakan lulusan IImu Komunikasi dari Universitas Kristen Petra Surabaya. Pengalaman Jurnalis nya dimulai dari Kota Surabaya di Jawa Pos Koran Surabaya selama 4 Tahun dan pindah ke Jawa Pos Koran Jakarta. Setelah balik ke kampong halaman, Ika aktif sampai saat ini sebagai Jurnalis Media Online TerasMaluku. 